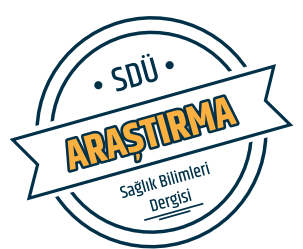

\title{
Hemşirelik Öğrencileri İçin Terapötik İletişim Becerileri Ölçeğinin Geliştirilmesi
}

\section{Developing a Therapeutic Communication Skills Scale for Nursing Students}

Aysel Karaca1, Ferhan Açıkgöz', Dilek Demirezen ${ }^{1}$

${ }^{1}$ Düzce Üniversitesi Sağlık Bilimleri Fakültesi, Hemşirelik Bölümü, Psikiyatri Hemşireliği Anabilim Dalı, Düzce, Türkiye.

\section{Özet}

Amaç: Araştırma hemşirelik öğrencileri için terapötik iletişim becerilerinin belirlenmesine yönelik bir ölçme aracının geliştirilmesi amacıyla metodolojik tasarımda gerçekleştirilmiştir.

Materyal-Metot: Araştırma bir üniversitenin hemşirelik bölümünde öğrenim gören ve klinik uygulama yapan ikinci, üçüncü ve dördüncü sınıf lisans öğrencileri ile yürütülmüştür. Fakültede bu özelliklere sahip ve araştırmaya katılmaya gönüllü olan toplam 367 hemşirelik öğrencisinden veri toplanmıştır. İki hafta ara sonra 367 kişiden 60'ına ölçek tekrar test analizi için ikinci kez uygulanmıştır. Çalışma verileri SPSS Statistics 23 ve IBM SPSS Amos 21 programlarına aktarılarak analizler tamamlanmıştır. Veriler değerlendirilirken sayısal değişkenler için tanımlayıcı istatistikler (ortalama, standart sapma, minimum, maksimum) verilmiştir. Ölçeğin faktör yapısının belirlenmesinde açımlayıcı ve doğrulayıcı faktör analizi yapılmıştır.

Bulgular: Ölçeğin yapı geçerliliği için yapılan faktör analizi ile ölçeğin üç faktörlü yapı sergilediğine ve toplam 16 maddeden oluştuğuna karar verilmiştir. "Hemşirelik Öğrencileri İçin Terapötik İletişim Becerileri” ölçeğinin Cronbach Alfa değeri 0,775, "NonTerapötik İletişim Becerileri” alt boyutunun Cronbach Alfa değeri 0,826, "Terapötik İletişim Becerileri 1 " alt boyutunun Cronbach Alfa değeri 0,791 ve "Terapötik İletişim Becerileri 2" Cronbach Alfa değeri 0,601 olarak bulunmuştur.

Sonuç: "Hemşirelik Öğrencileri İçin Terapötik İletişim Becerileri Ölçeği" 16 maddeden ve nonterapötik iletişim becerileri, terapötik iletişim becerileri 1 ve terapötik iletişim becerileri 2 olmak üzere üç alt boyuttan oluşmaktadır. Oluşturulan ölçeğin hemşirelik öğrencileri grubunda geçerli ve güvenilir bir ölçek olarak kullanılabileceği belirlenmiştir.

Anahtar kelimeler: İletişim, Hemşirelik Öğrencileri, Güvenilirlik ve Geçerlilik.

\begin{abstract}
Objective: This methodological study aimed to develop a measurement tool to determine the therapeutic communication skills of nursing students.
\end{abstract}

Material-Method: This study was carried out with sophomore, junior and senior undergraduates who were studying at the nursing school of a university and involved in practical clinical training. The data were collected from 367 nursing students who participated voluntarily. The scale was re-administered to 60 participants at two-week intervals for the retest analysis. The data analyses were done with SPSS Statistics 23 and IBM SPSS Amos 21 software using descriptive statistics (means, standard deviations, minima and maxima) as numeric variables. Exploratory and confirmatory factor analyses were carried out to define the scale's factorial structure.

Results: The factorial analysis performed to verify the scale's structural validity determined that it had a three-factor structure with 16 items. The study found that the Cronbach's alpha values for the scales of "Therapeutic Communication Skills for Nursing Student" was 0.775, sub-scales of Non-Therapeutic Communication Skills, Therapeutic Communication Skills 1, Therapeutic Communication Skills 2 were $0.826,0.791$ and 0.601 , respectively.

Conclusions: The Therapeutic Communication Skills Scale for Nursing Students contains 16 items in three subdimensions: non-therapeutic, therapeutic communication skills 1 and therapeutic communication skills 2 . It is a valid and reliable scale and can be administered to nursing student groups.

Keywords: Communication, Nursing Students, Reliability and Validity.

\section{Giriş}

Hemşirenin temel işlevi, hasta ve sağlıklı bireylerin kendi kendilerine karşılayamadıkları gereksinmelerini tanımalarına ve karşılamalarına yardımcı olmaktır. Hemşire kuramcılarından Peplau 1950'li yıllarda hemşireliği kişilerarası tedaviye yönelik vazgeçilmez bir süreç olarak tanımlamış, "hemşireliğin kalbi” diye nitelendirdiği hemşire-hasta ilişkisinin önemini vurgulamıştır (1). Hemşire kuramcılarından King, Travelbee ve Orlanda' da hasta-hemşire etkileşiminin önemini vurgulayarak hemşireliği "kişilerarası etkileşim sürecidir” şeklinde tanımlamışlardır $(2,3)$.

Terapötik iletişim becerileri etkili bir iletişim için ön koşuldur ve sağlıklı/hasta bireyin duygularını, düşüncelerini ve niyetini rahatça ifade etmesini kolaylaştıran tekniklerden 
oluşur Hemşirenin hastayla kurduğu ilişkide hedeflerinden biri, bireyin kendini "değerli bir kişi”" olarak algılamasını ve emin ellerde olduğunu hissetmesini sağlamaktır. (3-6). $\mathrm{Bu}$ teknikleri kullanan hemşire, hasta bakımını planlarken hasta için ya da hasta adına değil, hasta ile birlikte hareket eder $(3,7)$. Literatürde hemşirenin hastayla kurduğu kişiler arası ilişkinin hastalığın gidiş ve sonucunu belirlemede önemli etken olduğu, bu ilişkinin "ağrı tedavisinde morfin kullanılması kadar önemli ve yararlı olabileceğini veya tam aksine açık bir yaraya toz ve tuz serpmeye benzer biçimde kullanılabileceğini" belirtilmektedir $(3,8,9)$. Son y1llarda yapılan araştırmalarda hastalarla kurulan iyi iletişimin hasta memnuniyeti, bakım kalitesi, hastanın tedavi/bakım süreçlerine katılma ve sonuçlar üzerine olumlu etkileri olduğunu vurgulanmıştır (4, 10-12). Bu nedenle, etkili iletişim kurulmasında hemşirelere önemli sorumluklar düşmektedir. Hemşirelikte iletişim bakımın vazgeçilmez bir parçası olmasına rağmen bazı araştırma sonuçları hemşirelerin terapötik iletişim becerilerinin yeterli düzeyde olmadığını göstermektedir. (13, 14). İletişim becerileri öğrencilik yıllarında kazanıldığından hemşirelik eğitimcilerine önemli görevler düşmekte ve hemşirelik eğitiminde iletişim becerilerinin titizlikle verilmesi önem kazanmaktadır (15). Türkiye'de hemşirelik bölümlerinde eğitim sürecinde en az bir kez iletişim becerileri dersi verilmektedir. Araştırmanın planlandığı hemşirelik bölümünün müfredatında farklı durumları ele alan toplam altı farklı iletişim dersi bulunmaktadır. Hemşireliğe özgü mesleki iletişim becerilerinin ne düzeyde geliştiğinin belirlenmesi de önemlidir.

Bu araştırmanın amacı, Hemşirelik Öğrencileri İçin Terapötik İletişim Becerileri Ölçeğinin (HÖTİBÖ) geliştirilmesi, geçerlik ve güvenirliğini belirlenmesidir. Ulusal literatüre kazandırılması hedeflenen bu ölçek ile hemşirelik öğrencilerinin terapötik iletişim becerilerinin gelişmesine katk1 sağlayacağı düşünülmektedir.

\section{Materyal-Metot}

$\mathrm{Bu}$ çalışma bir ölçek geliştirme çalışmasıdır. Araştırmanın evrenini, 2017-2018 öğretim yılı bahar yarıyılında bir üniversitenin sağlık bilimleri fakültesi hemşirelik bölümünde öğrenim gören ve klinik uygulama yapan ikinci, üçüncü ve dördüncü sınıf lisans öğrencileri oluşturmuştur. Fakültede bu özelliklere sahip olan toplam 570 öğrenci bulunmaktadır. Ölçek çalışmalarında her bir ölçek maddesinin üç-dört katı veya daha fazlasının örnekleme alınması önerilmektedir. $\mathrm{Bu}$ nedenle araştırmanın örneklemi de 24 maddelik ölçek sayısının 10 katı üstü olacak şekilde belirlenmiştir (16). Herhangi bir örneklem seçimine gidilmemiş, uygulamanın yapıldığı günlerde devamsızlık yapan ve araştırmaya katılmak istemeyen öğrenciler dışındaki tüm öğrenciler araştırma kapsamına alınmıştır. "HÖTİBÖ”, araştırmaya katılmaya gönüllü olan 367 hemşirelik öğrencisine uygulanmıştır. İki hafta aradan sonra 367 kişiden 60'ına ölçek tekrar test analizi için ikinci kez uygulanmıştır. HÖTİBÖ geliştirme çalışmaları aşağıda verilmiştir.

Madde Havuzunun Oluşturulması Aşaması: Araştırmanın ilk aşamasında hemşirelik ve terapötik iletişim becerileri literatüründen elde edilen bilgiler doğrultusunda 24 maddeden oluşan bir madde havuzu oluşturulmuştur $(3,17)$. Maddeler tasarlanırken, maddelerin sade ve anlaşılır olmasına, bir maddenin birden fazla yarg1 ve düşünce ifadesine sahip olmamasına özen gösterilmiştir.

Uzman Görüşünün Alınması (İçerik Geçerliliği (Content Validity) ve Görünüm Geçerliliği (Face Validity) Aşaması: $\mathrm{Bu}$ aşamada maddelerin gerekliliği, açık ve özgüllüğünün değerlendirmesi için altı (psikiyatri hemşireliği akademisyenleri psikoloji akademisyenleri ve biyoistatik uzmanı) uzmandan görüş alınmıştır. Uzman değerlendirmesinde maddeler Davis tekniğine göre; "uygun", "madde hafifçe gözden geçirilmeli", "madde ciddi olarak gözden geçirilmeli" ve "madde uygun değil” şeklinde dörtlü derecelendirilmiştir (18, 19). Maddelerin "uygun” oluşu ve maddenin "hafifçe gözden geçirilmeli" seçeneklerini işaretleyen uzmanların sayısı toplamuzman sayısına bölünerek maddeye ilişkin "kapsam geçerlik indeksi" 0,80 bulunmuş ve bu değer kabul edilebilir düzeydedir (19). Değerlendirme sonuçlarına göre maddeler düzenlenmiş ve 24 maddelik bir taslak form oluşturulmuştur. Uzmanların görüşlerine göre ölçeğe bir madde daha eklenmiş (toplam 25 madde) ve ölçek maddeleri yeniden düzenlenmiştir. Geliştirdiğimiz bu ölçek, hemşirelik öğrencilerinin eğitim yaşantılarında öğrendikleri ve klinik uygulamaları sırasında kullandıkları terapötik (etkili/hasta yararına) ve nonterapötik (etkisiz/hasta yararına olmayan) iletişim becerisi örneklerinden oluşmaktadır. Ölçek 7'li likert (1 Asla, 4 Ara sıra, 7 Her zaman) tarzında kendini değerlendirme ölçeğidir.

Pilot Uygulama Aşaması: 25 maddelik taslak ölçeğin ön uygulamada anlaşılırlığı test edilmiştir. Bu amaçla 15 hemşirelik öğrencisine taslak ölçek uygulanmıştır. Katılımcılardan, 7'li Likert tipi ölçek üzerinde kendi algılarını ifade etmeleri beklenilmiştir. Katılımcılardan anlaşılması güç olan maddeleri işaretlemesi istenmiştir. "Anlaşılmıyor" ve "ifadesi değişebilir" yanıtı alınan maddeler düzenlenerek ölçeğe 24 maddelik son halini verilmiştir. Pilot uygulamaya alınan öğrenciler araştırma evrenine dahil edilmemiştir.

Araştırmaya katılmayı kabul eden öğrencilerin yazılı onam alındıktan sonra araştırmacılar tarafından hazırlanan veri toplama araçları sınıf ortamında ve bir öğretim elamanı rehberliğinde toplanmıştır. $\mathrm{Bu}$ uygulama sırasında öğrencilere iki hafta sonra tekrarlanacak ölçek uygulaması için bilgilendirme yapılmıştır. Tekrar test için gönüllü olan öğrencilere form iki hafta sonra sınıf ortamında uygulanmıştır. Ölçek formunun uygulama süresi yaklaşık olarak 20-30 dakika sürmüştür.

Test-tekrar test yönteminde iki uygulama arasındaki sürenin ne kadar olacağ 1 konusu önemlidir. Test-tekrar test yönteminin uzun zaman aralığında uygulanabilmesi için ölçülen özelliğin kararlı bir yapıya sahip olması gerekmektedir. Bu ve benzeri nedenlerle tüm testler / ölçekler farklı zaman aralığında uygulanmaktadır. Fiziksel dayanıklılık, güç ölçümü gibi testlerde ikinci testin uygulanması için en az bir haftalık sürenin geçmesi gerekmektedir. Çünkü kişilerin bu süre zarfında kendilerini toparlamaları gerekmektedir. Fiziksel performans ölçümlerinin güvenirliğini ölçmek için birinci 
ölçüme katılanların tümünün test-tekrar test yöntemine katılması zorunlu değildir. İlk teste (ölçüme) katılanların \%25-50'sinin testi tekrar alması yeterli olabilmektedir (20). Çalışma verileri SPSS Statistics 23 ve IBM SPSS Amos 21 programlarına aktarılarak analizler tamamlanmıştır. Veriler değerlendirilirken sayısal değişkenler için tanımlayıcı istatistikler (ortalama, standart sapma, minimum, maksimum) verilmiştir. Ölçek için öncelikle açımlayıcı faktör analizi uygulanmıştır (IBM SPSS Statistics 23). Açımlayıcı faktör analizi sonuçlarına göre oluşan boyutların yapısı doğrulayıcı faktör analizi ile doğrulanmış (IBM SPSS Amos 21), güvenilirlik analizi (Cronbach Alfa) uygulanmış ve sınıf içi korelasyon katsayısı (ölçek maddelerinin zamana göre değişip değişmediğini) kontrol edilmiştir.

Etik Konular: Geliştirilen ölçek formunun uygulanabilmesi bir üniversitenin Girişimsel Olmayan Etik Kurulu'ndan onay (kabul no:2018/95) ve araştırmanın yapıldı̆̆ı fakülte dekanlığından gerekli izinler alınmıştır. Araştırmaya katılan öğrencilere çalışmanın amacı ve yöntemi konusunda yazılı ve sözlü olarak bilgi verilip, katılımın gönüllülük esasında dayandığı açıklanmıştır.

Veriler kişisel bilgi formu ve HÖTİBÖ ile toplanmıştır.

Kişisel Bilgi Formu: Öğrencilerin sosyodemografik özelliklerini, eğitim süresince aldıkları iletişim derslerini sorgulayan toplam 8 soru bulunmaktadır.

Hemşirelik Öğrencileri İçin Terapötik İletişim Becerileri Ölçeği (HÖTİBÖ): Geliştirilen bu ölçeğin özellikleri bulgular bölümünde verilmiştir. Ölçeğin yapılan analizler sonucunda birinci alt boyutun 7 maddeden, ikinci alt boyutun 6 maddeden, üçüncü alt boyutun 3 maddeden olmak üzere toplam 16 maddeden oluştuğu görülmektedir (Tablo 3). 7'li likert 16 maddeden oluşan HÖTİBÖ’ de ters kodlu soru bulunmamaktadır. Ölçekten alınabilecek maksimum puan $16 \times 7=112$ minimum puan ise $16 \times 1=16$ 'dır. NonTerapötik İletişim Becerileri alt boyutundan alınabilecek maksimum puan $7 \times 7=49$ minimum puan ise $7 \times 1=7$ 'dir.Terapötik İletişim Becerileri 1 alt boyutundan alınabilecek maksimum puan $6 \times 7=42$ minimum puan ise $6 \times 1=6$ 'dır. Terapötik İletişim Becerileri 2 alt boyutundan alınabilecek maksimum puan $3 \times 7=21$ minimum puan ise $3 \times 1=6$ 'tür.

Araştırmanın örneklemi çalışmanın yapıldığı Sağlık Bilimleri Fakültesi Hemşirelik Lisans programına devam eden öğrenciler ile sınırlıdır. Çalışma sonuçları bu örnekleme genellenebilir.

\section{Bulgular \\ Verilerin Uygunluğu ve Örneklem Yeterlilik Testi Sonuçları \\ Açımlayıcı Faktör Analizi}

Faktör analizi birbirleriyle ilişkili çok sayıda değişkeni bir araya getirerek kavramsal olarak anlamlı daha az sayıda yen değişkenler (Faktörler, Boyutlar) bulmayı amaçlayan çok değişkenli bir istatistiktir. Faktör analizi sonucunda belli bir faktör altında toplanan göstergelerin, kuramsal yapının göstergeleri olup olmadığına yönelik bir sorgulama yapılmaktadır. Faktör analizi, doğasında varolan iç bağımlılıkların getirdiği avantaj sayesinde, verilerin karmaşıklığını azaltır ve böylece az sayıda faktör ile genelde çok sayıda orijinal gözlemin oluşturduğu geniş verilerin sunduğu bilgi miktarının hemen hemen aynısını sunmaktadır. Açımlayıcı faktör analizi uygulayabilmek için iki varsayım bulunmaktadır. Bunlar KMO ve Bartlett testleridir.

KMO testi: Faktör analizinde örneklem büyüklüğünün uygunluğunu test etmede kullanılır. KMO değerinin 0,50'den düşük çıkması halinde faktör analizine devam edilmez. Bulunun KMO değerine bağlı olarak örneklem büyüklüğü hakkında şu yorumlar yapılır:

$$
\begin{aligned}
& \text {-0,50-0,60 aras1 "kötü”, } \\
& -0,60-0,70 \text { aras1 "zayıf”, } \\
& \text {-0,70-0,80 aras1 "orta", } \\
& \text {-0,80-0,90 aras1 "iyi”, } \\
& \text {-0,90 üzeri "mükemmel". }
\end{aligned}
$$

KMO değerinin 0,50'den düşük çıkması durumunda, daha fazla veriyi işleme katmak gerektiği anlaşılmaktadır $(16,20)$. Bartlett testi: Verilerin çok değişkenli normal dağılımdan gelip gelmediğini belirlemede kullanılır. Bu test sonucunda bir ki kare değeri elde edilir ve anlamlılık değerine bakılır. Anlamlılık değeri, 0,05 'ten küçük ise verilerin çok değişkenli normal dağılımdan geldiği söylenir ve analize devam edilir. Anlamlılık değeri 0,05 'ten büyük ise faktör analizi sonuçlarının kullanılamaz olduğu sonucuna varılır $(16,20)$. $\mathrm{Bu}$ çalışmada, yapılan analizler sonucunda KMO değeri 0,852 ve Bartlett Küresellik testi sonucu ise değişkenler arasında anlamlı düzeyde yüksek ilişkiler bulunduğu ve verilerin faktör analizi uygulamak için uygun olduğu sonucuna ulaşılmıştır (Tablo 1). Bu bulgular örneklem büyüklüğünün yeterli ve toplanan verilerin faktör analizi için uygun olduğunu göstermektedir.

Tablo 1. Terapötik iletişim becerileri ölçeğinin KMO değeri ve Bartlett Küresellik Testi sonuçları

\begin{tabular}{lcc}
\hline KaiserMeyerOlkin (KMO) & & 0,852 \\
\hline \multirow{2}{*}{ Bartlett Küresellik Testi } & $\mathrm{X}^{2}$ & 1670,454 \\
\cline { 2 - 3 } & $\mathrm{sd}$ & 120 \\
\cline { 2 - 3 } & $\begin{array}{c}\mathrm{p} \text {; Anlamlıl1k } \\
\text { düzeyi }\end{array}$ & $0,000^{*}$ \\
\hline
\end{tabular}

$*: \mathrm{p}<0,05$

\section{Açıklanan Toplam Varyans}

Açıklanan varyans oranı, ölçeğin faktör yapısının gücünü gösterir. Ölçeğin 24 madde üzerinden faktör yapısı açıklanan toplam varyans ile analiz edilmiş ve 1'in üzerinde özdeğere sahip toplam varyansın \%51,6'sını oluşturan 3 faktör bulunmuştur (Tablo 2). "NonTerapötik İletişim Becerileri" alt boyutu toplam varyansın \%21,051'ini, “Terapötik İletişim Becerileri 1" alt boyutu toplam varyansin \%18,887'sini ve "Terapötik İletişim Becerileri 2" alt boyutu ise toplam varyansın \%11,678'ini açıklamaktadır. "NonTerapötik İletişim Becerileri”, "Terapötik İletişim Becerileri 1" ve "Terapötik İletişim Becerileri 2" alt boyutları birlikte toplam varyansın \%51,616'sını açıklamaktadır.

$\mathrm{Bu}$ ölçek geliştirme çalışması kapsamında faktör yapısının belirlenmesi amaciyla 24 maddelik formda faktör yükü 30'un üstünde olan ve birden fazla faktöre yüklenmeyen 
Tablo 2. Terapötik iletişim becerileri ölçeğinin varyans açıklama tablosu

\begin{tabular}{lcccccc}
\hline \multirow{2}{*}{ Faktör } & \multicolumn{3}{c}{ Başlangıç Özdeğerleri } & \multicolumn{2}{c}{ Toplam Faktör Yükleri (Döndürülmüş) } \\
\cline { 2 - 7 } & Toplam & $\begin{array}{c}\text { Açılanan } \\
\text { Varyans \% }\end{array}$ & Birikimli \% & Toplam & $\begin{array}{c}\text { Açıklanan } \\
\text { Varyans \% }\end{array}$ & Birikimli \% \\
\hline NonTerapötik İletişim Becerileri & 3,861 & 24,129 & 24,129 & 3,368 & 21,051 & 21,051 \\
\hline Terapötik İletişim Becerileri1 & 3,312 & 20,702 & 44,832 & 3,022 & 18,887 & 39,938 \\
\hline Terapötik İletişim Becerileri2 & 1,085 & 6,784 & 51,616 & 1,868 & 11,678 & $\mathbf{5 1 , 6 1 6}$ \\
\hline
\end{tabular}

Tablo 3. Terapötik iletişim becerileri ölçeğinin maddelerine ilişkin faktör yükleri

\begin{tabular}{|c|c|c|c|}
\hline & $\begin{array}{c}\text { NonTerapötik İletişim } \\
\text { Becerileri }\end{array}$ & $\begin{array}{l}\text { Terapötik İletişim } \\
\text { Becerileri } 1\end{array}$ & $\begin{array}{l}\text { Terapötik İletişim } \\
\text { Becerileri } 2\end{array}$ \\
\hline Uyarmak (Madde 24) & 0,752 & & \\
\hline DuygularıAzımsamak (Madde 10) & 0,712 & & \\
\hline Nasihat /ÖğütVermek (Madde 22) & 0,701 & & \\
\hline BelirsizGüvenceKlişeOtoYanıt (Madde 2) & 0,685 & & \\
\hline KonuyuDeğiş̧tirmek (Madde 23) & 0,683 & & \\
\hline Savunmak (Madde 9) & 0,664 & & \\
\hline Yargilamak (Madde 14) & 0,587 & & \\
\hline Yansitma (Madde 18) & & 0,778 & \\
\hline Özetleme (Madde 17) & & 0,705 & \\
\hline YenidenTekrarlama (Madde 19) & & 0,654 & \\
\hline İmalarıSözelleştirme (Madde 11) & & 0,642 & \\
\hline Yoğunlaşma (Madde 20) & & 0,636 & \\
\hline Gözlemleriİletme (Madde 8) & & 0,616 & \\
\hline AktifDinleme (Madde 3) & & & 0,705 \\
\hline Varlığını Sunma (Madde 1) & & & 0,663 \\
\hline Soru Sorma (Madde 4) & & & 0,570 \\
\hline
\end{tabular}

maddeler dikkate alınmıștır. HÖTİBÖ 24 madde ile analizlere sokulmuştur. Analiz sırasında 5, 6, 7, 12, 13, 15, 16 ve 21 numaralı maddeler binişik maddeler oldukları için yapıdan çıkarılmıştır. Tüm düzenlemeler sonunda toplam madde sayısı 16 olarak belirlenmiştir. Bu işlemlere bağlı olarak ölçeğin üç faktör altında toplandığı görülmüştür (Tablo 3). Tablo 3'de ölçeğin maddelerine ilişkin faktör yük değerlerinin 0,570 ile 0,778 arasında değiştiği görülmektedir.

Hemşirelik Öğrencileri için Terapötik İletişim Becerileri Ölçeği'nin Doğrulayıcı Faktör Analizi Sonuçlarına Ait Bulgular

Doğrulayıc faktör analizinde (DFA) 0,30 ve üzerinde faktör yük değeri bulunan maddeler faktör yapısına alınmıştır. 16 madde 3 alt boyut ile oluşturulan ölçüm modeli için uyum indeks değerleri yer almaktadır. Ölçüm modeli için elde edilen uyum indeks değerleri incelendiğinde ise Ki Kare / Serbestlik Derecesi $\left(\chi^{2} / \mathrm{sd}\right)$, Goodness of fit index (GFI), Adjusted goodness of fit index (AGFI), Incremental Fit Index (IFI), Root Mean Square of Error Approximation (RMSEA) ve Standardized Root Mean Residual (SRMR) değerlerinin iyi uyum sağladığını Non-Normed Fit Index (TLI(NNFI)) ve Comparative Fit Index (CFI) değerlerinin ise kabul edilebilir uyum sağladığını söyleyebiliriz $(16,20)$ (Tablo 4). Sonuç olarak açımlayıcı faktör analizinden sonra ölçüm modeli doğrulanmıştır (Şekil 1).

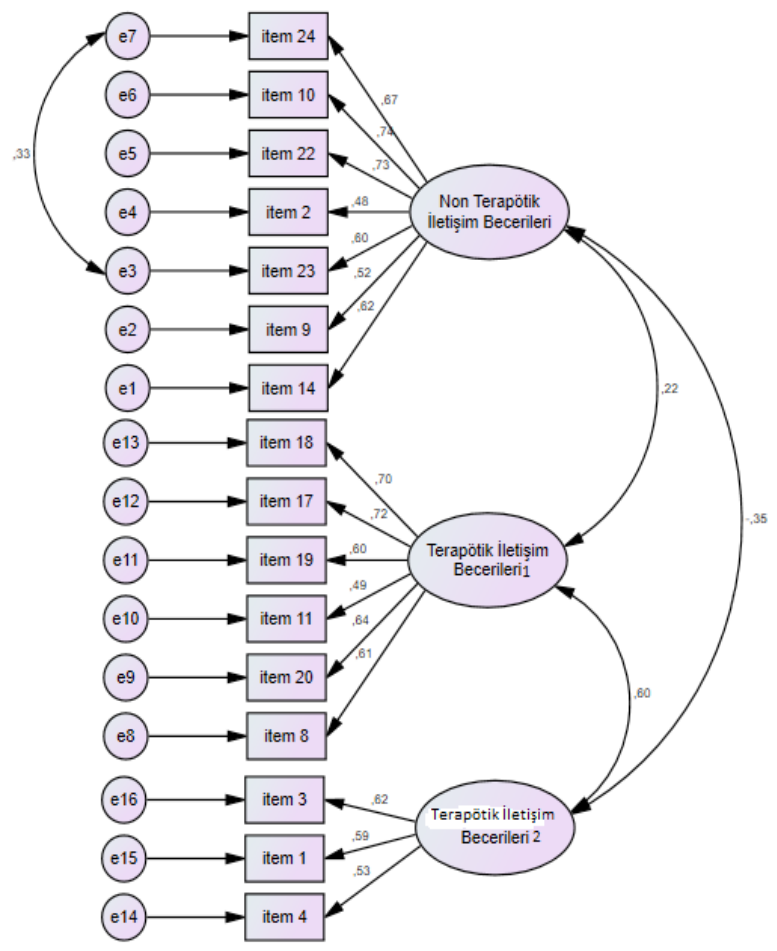

Şekil 1. Terapötik iletişim becerileri ölçeğinin ölçüm modeli 
Tablo 4. Doğrulayıcı faktör analizinin uyum indeks değerleri ve iyi uyum değerleri

\begin{tabular}{lcc}
\hline & $\begin{array}{c}\text { Model Uyum } \\
\text { Indeks Değerleri }\end{array}$ & $\begin{array}{c}\text { İyi Uyum Değerleri } \\
\text { (Kabul } \\
\text { Edilebilir Uyum) }\end{array}$ \\
\hline$\chi^{2} /$ sd & 1,600 & $\leq 3(4-5)$ \\
GFI & 0,949 & $\geq 0,90(0,89-0,85)$ \\
AGFI & 0,931 & $\geq 0,90(0,89-0,85)$ \\
IFI & 0,963 & $\geq 0,95(0,94-0,90)$ \\
TLI (NNFI) & 0,906 & $\geq 0,95(0,94-0,90)$ \\
CFI & 0,962 & $\geq 0,97(0,95)$ \\
RMSEA & 0,040 & $\leq 0,05(0,06-0,08)$ \\
SRMR & 0,046 & $\leq 0,05(0,06-0,08)$ \\
\hline
\end{tabular}

$\chi^{2} /$ sd: Ki Kare / Serbestlik Derecesi

GFI: Goodness of fit index

AGFI: Adjusted goodness of fit index

IFI: Incremental Fit Index

TLI (NNFI): Non-Normed Fit Index

CFI: Comparative Fit Index

RMSEA: Root Mean Square of Error Approximation

SRMR: Standardized Root Mean Residual
16 maddeden oluşan yapıyı doğrulamak için kurulan ölçüm modeli analiz edilmiştir. Analiz sonucunda modelin yeterli uyum göstermediği görülmüş ve bu nedenle model iyileştirme çalışmaları yapılmıştır. Öncelikle modifikasyon indeksleri tablosuna bakılarak modelde yapılacak olas1 değişiklikler için ki kare düşüş değerleri (“M.I."değerleri) incelenmiştir. En yüksek "M.I." değerinin göstermiş olduğu modifikasyon, kavramsal olarak uygun olduğu durumlarda bağlanarak model yürütülmüştür. $\mathrm{Bu}$ nedenle sadece 1 modifikasyon ile sonuçların düzeldiği ve sonuç olarak modelin doğrulandığ1 görülmüştür. Doğrulanan ölçüm modeli Tablo 5'de sunulmuştur. Tabloda HÖTİBÖ'nün doğrulanan ölçüm modeli sonunda maddelere ilişkin standardize regresyon katsayıları diğer bir deyişle faktör yükleri bulunmaktadır. Görüldüğü gibi 0,400 'ün altında faktör yükü bulunmamaktadır.

\section{Faktörlerin Isimlendirilmesi}

Yapılan analizler sonrasında HÖTİBÖ’nün toplam madde sayısının 16 olduğu, faktör yapısının da 3 faktör altında toplandığ1 görülmüştür. Ölçekte birinci faktörde yer alan maddeler tedavi edici olmayan iletişim becerilerini (nonterapötik iletişim becerileri), ikinci faktörde yer alan maddeler terapötik iletişim becerileri 1'i, üçüncü faktörde yer alan maddeler terapötik iletişim becerileri 2'yi kapsamaktadır.

Tablo 5. Terapötik iletişim becerileri ölçeğinin faktör yük değerleri

\begin{tabular}{|c|c|c|c|}
\hline & $\begin{array}{c}\text { NonTerapötik İletişim } \\
\text { Becerileri }\end{array}$ & $\begin{array}{l}\text { Terapötik İletişim } \\
\text { Becerileri 1 }\end{array}$ & $\begin{array}{l}\text { Terapötik İletişim } \\
\text { Becerileri } 2\end{array}$ \\
\hline Uyarmak (Madde 24) & 0,671 & & \\
\hline DuygularıAzımsamak (Madde 10) & 0,745 & & \\
\hline Nasihat /Öğ̈̈tVermek (Madde 22) & 0,733 & & \\
\hline BelirsizGüvenceKlişeOtoYanıt (Madde 2) & 0,481 & & \\
\hline KonuyuDeğiştirmek (Madde 23) & 0,599 & & \\
\hline Savunmak (Madde 9) & 0,523 & & \\
\hline Yargilamak (Madde 14) & 0,624 & & \\
\hline Yansitma (Madde 18) & & 0,701 & \\
\hline Özetleme (Madde 17) & & 0,721 & \\
\hline YenidenTekrarlama (Madde 19) & & 0,597 & \\
\hline İmalarıSözelleştirme (Madde 11) & & 0,491 & \\
\hline Yoğunlaşma (Madde 20) & & 0,636 & \\
\hline Gözlemleriİletme (Madde 8) & & 0,609 & \\
\hline AktifDinleme (Madde 3) & & & 0,623 \\
\hline Varlığını Sunma (Madde 1) & & & 0,593 \\
\hline Soru Sorma (Madde 4) & & & 0,528 \\
\hline
\end{tabular}

Tablo 6. Ölçek ve alt boyutlarının güvenilirlik analizi sonuçları

\begin{tabular}{lccc}
\hline & Madde Sayısı & Cronbach Alfa & Güvenilirlik Düzeyi \\
\hline Terapötik İletişim Becerileri & 16 & 0,775 & Güvenilir \\
Ölçeği Alt Boyutları & 7 & 0,826 & Yüksek Güvenilir \\
NonTerapötik İletişim Becerileri & 6 & 0,791 & Güvenilir \\
Terapötik İletişim Becerileri1 & 3 & 0,601 & Güvenilir \\
Terapötik İletişim Becerileri2 & & &
\end{tabular}


Tablo 7. Terapötik iletişim becerileri ölçeği için test-tekrar test arasındaki uyum

\begin{tabular}{lccc}
\hline & Sınıf İçi Korelasyon (ICC) & \%95 Güven Aralı̆̆ı & p \\
\hline Terapötik İletişim Becerileri Ölçeği & 0,720 & $0,572-0,823$ & $0,000^{*}$ \\
NonTerapötik İletişim Becerileri & 0,696 & $0,538-0,806$ & $0,000^{*}$ \\
Terapötik İletişim Becerileri1 & 0,682 & $0,519-0,797$ & $0,000^{*}$ \\
Terapötik İletişim Becerileri2 & 0,614 & $0,428-0,750$ & $0,000^{*}$ \\
\hline
\end{tabular}

*: $<00,05$

Tablo 8. Terapötik iletișim becerileri ölçeği için ve alt boyutları için tanımlayıcı

\begin{tabular}{lcccc}
\hline İstatistikler & & & & \\
\hline $\mathbf{n = 3 6 7}$ & Ortalama & St. Sapma & Minimum & Maksimum \\
\hline NonTerapötik İletişim Becerileri & 23,84 & 7,92 & 7,00 & 43,00 \\
Terapötik İletişim Becerileri1 & 27,61 & 5,67 & 8,00 & 42,00 \\
Terapötik İletişim Becerileri2 & 16,92 & 2,66 & 6,00 & 21,00 \\
Terapötik İletişim Becerileri Ölçeği & 68,38 & 11,07 & 28,00 & 98,00 \\
\hline
\end{tabular}

\section{Madde Güvenirliğine Ait Bulgular}

İç tutarlılığa ilişkin sonuçlar Tablo 6'da verilmiştir. Ölçeğin güvenirliğini belirlemek için iç tutarlık analizi yapılmıştır ve Cronbach Alfa değeri hesaplanmıştır. Uygulanan güvenilirlik analizi sonucunda, "HÖTİBÖ" ölçeğinin Cronbach Alfa değeri 0,775, "NonTerapötik İletişim Becerileri” alt boyutunun Cronbach Alfa değeri 0,826, "Terapötik İletişim Becerileri 1" alt boyutunun Cronbach Alfa değeri 0,791 ve “Terapötik İletişim Becerileri 2" Cronbach Alfa değeri 0,601 olduğu saptandığından ölçeğin yeterli iç tutarlılığa sahip olduğu söylenebilir.

Güvenirlik analizi ile hazırlanan ölçeğin, zamana göre değişmezlik gösterebilme gücüne test-tekrar test güvenirliği denir (21). HÖTİBÖ’nün kararlılığını ölçmek için çalışmaya katılın 367 kişiden 60'ına bir süre sonra ölçek tekrar uygulanmış, 15 gün arayla yapılan iki uygulama arasında sınıf içi korelasyon katsayısı (Intraclass Correlation Coefficient) ile hesaplanmıştır (Tablo 7). Uygulanan tekrar test ile ilk test arasında ölçek ve alt boyutlarında uyum olduğu görülmektedir. Buna göre HÖTİBÖ ve alt boyutlarında zamana bağlı bir değişim oluşmamaktadır.

\section{Ölçeğin Tanımlayıcı İstatistik Sonuçları}

Çalışmaya katılan kişilerin NonTerapötik İletişim Becerileri alt boyutu düzeyi 23,84 7 ,92 iken Terapötik İletişim Becerileri 1 alt boyutu düzeyi 27,61 $\pm 7,92$ ve Terapötik İletişim Becerileri 2 alt boyutu düzeyi ise $16,92 \pm 2,66$ 'dır. HÖTİBÖ düzeyleri ise $68,38 \pm 11,07$ 'dir (Tablo 8).

\section{Ölçeğin Değerlendirilmesi}

Ölçeğin yapılan analizler sonucunda birinci alt boyutun 7 maddeden, ikinci alt boyutun 6 maddeden, üçüncü alt boyutun 3 maddeden olmak üzere toplam 16 maddeden oluştuğu görülmektedir (Tablo 3). 7'li likert 16 maddeden oluşan Terapötik İletişim Becerileri Ölçeğinde ters kodlu soru bulunmamaktadır. Ölçekten alınabilecek maksimum puan $16 \times 7=112$ minimum puan ise $16 \times 1=16$ 'dır. NonTerapötik İletişim Becerileri alt boyutundan alınabilecek maksimum puan $7 \times 7=49$ minimum puan ise $7 \times 1=7$ 'dir.Terapötik İletişim Becerileri 1 alt boyutundan alınabilecek maksimum puan $6 \times 7=42$ minimum puan ise $6 \times 1=6$ 'dir. Terapötik İletişim
Becerileri 2 alt boyutundan alınabilecek maksimum puan $3 \times 7=21$ minimum puan ise $3 \times 1=6$ 'tür.

\section{Tartışma}

Geleceğin hemşireleri olan bugünün öğrencileri kalite bakım için etkili iletişim kurmak zorundadırlar. Hemşirelik öğrencileri bakımını üstlendikleri hastaların sağlık durumlarını değerlendirmek ve gerekli eğitimleri verebilmek için terapötik iletişim becerilerini kullanmaları gerekmektedir. Terapötik iletişim becerilerinin kullanılması hasta yararına olduğu kadar hemşirelik öğrencisine de katkı sağlamaktadır. Öğrenci- hasta arasında kurulan etkileşimler öğrencilerin mesleki gelişimleri üzerine etkileri olmaktadır (6). Bu nedenle hemşirelik öğrencilerin terapötik iletişim becerilerini değerlendirmek için bir ölçme aracına ihtiyaç duyulmuştur. Literatürde ölçek geliştirme çalışmaları nitel veya niceliksel olarak yapılabileceği belirtilmektedir. Niceliksel süreçte, literatür ya da uzman tarafindan elde edilen aday ölçek formu hedeflenen örneklem grubuna deneme uygulaması yapılarak nihai form elde edilmesi ile sonuçlanır (21). Bu araştırmada konu ile ilgili literatür incelenmiş terapötik iletişim becerilerine yönelik sorular düzenlenmiştir $(3,17)$. Geçerlik ve güvenirlik çalışmasını yaptığımız HÖTİÖ, hemşirelik ögrencilerinin klinik alanda terapötik iletişim becerilerini ölçebilmesi açısından önemlidir. Bu ölçek hem hemşirelik öğrencilerinin terapötik iletişim becerileri hakkında öz farkındalığını sağlamaya, hem de eğitimcilerin iletişim ders içerik ve ders yöntemlerine katkı sağlayacaktır.

Hemşirelik öğrencilerinin terapötik iletişim becerilerini ölçmek amacıyla geliştirilen bu ölçek formunun uygulanması sonrasında geçerlik ve güvenirlik analizleri yapılmıştır.

Ölçek yedili likert tipi soru şeklinde hazırlanmıştır. Likert tipi sorular farklı sayıda seçenek sunması, uygulama, kodlama ve katılımcılar için kolay anlaşılır olması bakımından avantajlıdır (22). Geliştirilen HÖTİÖ 16 maddelik soru sayısı ile uygulamada zaman yönünden kolaylık sağlamaktadır.

Ölçeğin yap1 geçerliği için Açımlayıcı Faktör Analizi (AFA) yapılmıştır. Örneklem büyüklüğünün uygunluğu için Kaiser-Meyer-Olkin (KMO) ve Barlett Küresellik testleri ile değerlendirilmiş ve AFA için uygun olduğu belirlenmiştir. 
Doğrulayıcı faktör analiz (DFO) sonuçlarına göre elde edilen uyum iyiliği değerleri ile ölçeğin kabul edilebilir olduğu söylenebilir. HÖTİBÖ'nün toplam madde sayısının 16 olarak kaldığı, faktör yapısının da 3 faktör altında toplandığı belirlenmiştir. Bu faktörler nonterapötik iletişim becerileri, terapötik iletişim becerileri 1, terapötik iletişim becerileri 2 şeklinde isimlendirilmiştir. Maddelerin faktör yük değerleri 0,400'ün altında faktör yükü bulunmamaktadır. Bir ölçekteki maddelerin yük değerleri 0,40 ve üzerinde ise bu maddeler "çok iyi", 0,70 ve üzerinde ise "mükemmel" olarak değerlendirilebilir. Buna göre, ölçekteki maddeler ile ilgili faktörler arasında oldukça güçlü ilişkiler olduğu görülmektedir $(18,23)$.

Üç faktörlü açılım gösteren ölçeğin değerlendirilmesinde üç faktör ayrı ayrı değerlendirilecektir. Birinci faktör olan nonterapötik iletişim tekniklerini/becerilerinin değerlendirilmesi iletişimi engelleyen yaklaşımlardaki durumu görmek açısından önemlidir. İkinci ve üçüncü faktör olan terapötik iletişim becerileri 1 ve 2 hemşire-hasta iletişimini kolaylaştıran tekniklerin kullanım durumunu, terapötik iletişim becerileri 2 hemşire-hasta iletişimini başlatma ve sürdürme için gerekli olan iletişim becerilerinin kullanım durumunu yansitmaktadır. Analiz sonunda literatürün de desteklediği terapotik iletişim becerilerini iki ayrı faktör yapısına ayılması nedeniyle bu faktörler terapotik iletişim becerileri 1 ve 2 şeklinde isimlendirilmiştir. Çünkü iki faktör de aynı amaca hizmet etmektedir. Ölçekte bulunan iletişim becerileri literatüre uyumlu şekilde faktör yapılarına ayrılması ölçeğin kullanışlığı açısından önemli bir özelliktir. HÖTiBÖ’nün Cronbach's alfa katsay1sı 0,775, alt boyutlarının Cronbach's alfa katsayıları incelendiğinde NonTerapötik İletişim Becerileri” alt boyutunun 0,826 ile en yüksek, "Terapötik İletişim Becerileri 2" alt boyutunun ise 0,601 ile en düşük olduğu saptanmıştır. Literatüre göre Cronbach Alpha değeri 0,60 ile 0,80 arasında olduğunda ölçeğin oldukça güvenilir olduğu belirtilmektedir $(18,23)$. Güvenirlik değerleri göz önüne alındığında HÖTİBÖ’nün güvenilir olduğu bulunmuştur. İki haftalık test-tekrar test güvenirliğinde değişim olmadığı alt boyutlarında uyum olduğu görülmüştür.

HÖTİBÖ hemşirelik eğitimi yaşantısında tüm hemşirelik öğrencilerinde, öğrencilerin iletişim becerilerini değerlendirmek amacı ile kullanılabilir. Değerlendirme sonuçlarına göre hemşirelik eğitim müfredatına mesleki iletişim dersleri eklenmesi veya mevcut ders içerik ve yöntemlerinin gözden geçirilip güncellenmesine katk1 sağlayacağı düşünülmüştür. Ayrıca hemşire-hasta etkileşimi kalitesini artırmak için hemşirelik öğrencilerinin kendi iletişim becerilerini değerlendirmelerine firsat sağlayacaktır.

\section{Sonuç}

Hemşirelik öğrencileri için terapötik iletişim becerileri ölçeğinin geliştirilmesi amacıyla yapılan geçerlilik ve güvenilirlik araştırmasında "HÖTİBÖ" 16 maddeden ve nonterapötik iletişim becerileri, terapötik iletişim becerileri 1, terapötik iletişim becerileri 2 olmak üzere üç alt boyuttan oluşmaktadır. Oluşturulan ölçeğin hemşirelik öğrencileri grubunda geçerli ve güvenilir bir ölçek olarak kullanılabileceği belirlenmiştir.

\section{Kaynaklar}

1. Karaca S. Hemşireler için vazgeçilmez bir kavram: Kendini tanıma. Maltepe Üniversitesi Hemşirelik Bilim ve Sanatı Dergisi 2010; 3(1): 79-84.

2. Hagerty BM, Patusky KL. Reconceptualizing the nursepatient relationship. Journal of Nursing Scholarshıp 2003; 35(2): 145-50.

3. Özcan A. Hemşire- Hasta İlişkisi ve İletişim 2. Basım. Ankara, Sistem Ofset, 2006.

4. Kourkouta, L. Papathanasiou, LV. Communication in nursing practice, Mater Sociomed 2014; 26(1): 65-7.

5. Parlayan MA, Dökme S. Özel hastanelerdeki hemşire ve hastaların iletişim seviyelerinin değerlendirilmesi: bir hastane örneği. KSÜ Sosyal Bilimler Dergisi 2016; 13 (2): 265-84.

6. Abdolrahimi M, Ghiyasvandian S, Zakerimoghadam M, Ebadi A. Therapeutic communication in nursing students: A Walker \& Avant concept analysis. Electronic Physician 2017; 9(8): 4968-77.

7. Anoosheh M, Zarkhah S, Faghihzadeh S, Vaismoradi M. Nurse-patient communication barriers in Iranian nursing. Iternational Nursing Review 2009; 56(2): 243-49.

8. Bingöl G, Demir A. Amasya sağlık yüksekokulu öğrencilerinin iletişim becerileri. Göztepe Tıp Dergisi 2011; 26(4): 152-59.

9. Khoshnazar TA, Rassouli M, Akbari ME, Lotfi-Kashani F, Momenzadeh S, Rejeh N, Mohseny M. communication needs of patients with breast cancer: a qualitative study. Indian J Palliat Care 2016; 22(4): 402-09.

10. Maskor NA, Krauss SE, Muhamad M. Mahmood NHN. Communication competencies of oncology nurses in malaysia, Asian Pacific Journal Cancer Prev 2013; 14(1): 153-58.

11. Kourkouta L, Papathanasiou IV. Communication in nursing practice, Mater Sociomed 2014; 26(1): 65-67.

12. Shafakhak M, Zarshenas L, Sharif F, Sarvestani RS. Evaluation of nursing students' communication abilities in clinical courses in hospitals. Global Journal of Health Science 2015; 7(4): 323-28

13. Kruijver IP, Kerkstra A, Bensing JM, van de Wiel HB. Communication skills of nurses during interactions with simulated cancer patients. J Adv Nurs. 2001; 34(6): 772-9.

14. Yas IW, Mohammed SH. Assessment of nurses knowledge about therapeutic communication in psychiatric teaching hospitals at baghdad city. Kufa Journal For Nursing Sciences 2016; 6 (2): 1-7.

15. Xie J, Ding S, Wang C, Liu A. An evaluation of nursing students' communication ability during practical clinical training. Nurse Educ Today 2013; 33(8): 823-7.

16. Çokluk Ö, Şekercioğlu G, Büyüköztürk Ş. Sosyal bilimler için çok değişkenli istatistik SPSS ve Lisrel uygulamaları. 2.Bask1, Pegem Akademi, Ankara, 2010: 177-400

17. Acar Voltan N. Yeniden Terapötik İletişim. 7. Baskı, Nobel Yayın Dağıtım, Ankara, 2010.

18. Lawshe $\mathrm{CH}$. A quantitative approach to content validity. Personnel Psychology 1975; 28: 563-575.

19. Taşkın Ç, Akat Ö. Araştırma yöntemlerinde yapısal eşitlik modelleme: LISREL ile marka değeri ölçümü örnekleri. Ekin 
Basım Yayın Dağıtım, 2010: 25-28.

20. Alper R. Uygulamalı Çok değişkenli İstatistiksel Yöntemler. Detay Yayıncılık, Üçüncü Baskı,

Ankara 2011.

21. Çam O, Baysan Arabacı L. Tutum Ölçeği Hazırlamada Nitel Ve Nicel Adımlar. Hemşirelikte Araştırma Geliştirme Dergisi 2010; 2: 59-71.
22. Turan İ, Şimşek H, Aslan İ. Eğitim Araştırmalarında likert ölçeği ve likert tipi soruların kullanımı ve analizi. Sakarya Üniversitesi Eğitim Fakültesi Dergisi 2015; 30: 186-203.

23. Akgül A. Statistical Analysis Techniques and Analysis Methods in Medical Research. SPSS Applications. Higher Education Council Press, Ankara, 1997. 